\title{
Source Apportionment of Urban Ammonia and its Contribution to Secondary Particle Formation in a Mid-size European City
}

\author{
Laura Ehrnsperger*, Otto Klemm \\ Climatology Research Group, Institute for Landscape Ecology, University of Münster, 48149 \\ Münster, Germany
}

\section{ABSTRACT}

Ambient air pollution caused by fine particulate matter (PM) and trace gases is a pressing topic as it affects the vast majority of the world's population, with a particularly heavy influence in densely populated urban environments. Alongside nitrogen oxides $\left(\mathrm{NO}_{\mathrm{x}}\right)$ and $\mathrm{PM}$, ammonia $\left(\mathrm{NH}_{3}\right)$ is also a relevant air pollutant due to its role as a precursor of particulate ammonium. This is a study about the short-term temporal dynamics of urban $\mathrm{NH}_{3}$ concentrations in Münster, northwest Germany, the role of road traffic and agriculture as $\mathrm{NH}_{3}$ sources and about the importance of ammonia for secondary particle formation (SPF). The $\mathrm{NH}_{3}$ mixing ratio was rather high (mean: $17 \mathrm{ppb}$ ) compared to other urban areas and showed distinct diurnal maxima around $10 \mathrm{a} . \mathrm{m}$. and during the night at 9 p.m. The main source for ammonia in Münster was agriculture, but road traffic also contributed through local emissions from vehicle catalysts. $\mathrm{NH}_{3}$ from surrounding agricultural areas accumulated in the nocturnal boundary layer and contributed to SPF in the city center. Modeled emissions of $\mathrm{NH}_{3}$ as estimated by the Handbook for Emission Factors in combination with traffic counts were in the same magnitude for $\mathrm{NH}_{3}$. The size-resolved chemical composition of inorganic ions in $\mathrm{PM}_{10}$ was dominated by $\mathrm{NH}_{4}{ }^{+}\left(8.66 \mu \mathrm{g} \mathrm{m}^{-3}\right)$, followed by $\mathrm{NO}_{3}^{-}\left(3.89 \mu \mathrm{g} \mathrm{m}^{-3}\right)$, $\mathrm{SO}_{4}{ }^{2-}\left(1.58 \mu \mathrm{g} \mathrm{m}^{-3}\right)$ and $\mathrm{Cl}^{-}\left(1.33 \mu \mathrm{g} \mathrm{m}^{-3}\right)$. Particles in the accumulation range (diameter: 0.1$1 \mu \mathrm{m}$ ) showed the highest inorganic ion concentrations. The ammonium neutralization index J (111\%) indicated an excess of $\mathrm{NH}_{4}{ }^{+}$leading to mostly alkaline PM. High ammonia emissions from surrounding agricultural areas combined with large amounts of $\mathrm{NO}_{\mathrm{x}}$ from road traffic play a crucial role for SPF in Münster.

Received: July 15, 2020

Revised: November 20, 2020

Accepted: November 22, 2020

\section{${ }^{*}$ Corresponding Author:}

laura.ehrnsperger@wwu.de

\section{Publisher:}

Taiwan Association for Aerosol Research

ISSN: $1680-8584$ print

ISSN: 2071-1409 online

(c) Copyright: The Author(s).

This is an open access article distributed under the terms of the Creative Commons Attribution License (CC BY 4.0), which permits unrestricted use, distribution, and reproduction in any medium, provided the original author and source are cited.
Keywords: Ammonia sources, Road traffic, Agriculture, Urban air quality, Fine particulate matter

\section{INTRODUCTION}

A vast majority of the world's population (91\%) lives in locations that exceed the WHO air quality guidelines (WHO, 2016) with poor air quality responsible for one in every nine premature deaths in 2012 (WHO, 2016). Urban areas are especially prone to high levels of pollutants with an increasing frequency of air pollution episodes in many cities (WHO, 2016). This is due to the fact that the density of anthropogenic emission sources is higher in urban areas compared to rural regions. Air quality monitoring mainly focuses on particulate matter (PM), tropospheric ozone $\left(\mathrm{O}_{3}\right)$, and oxygenated $\mathrm{N}-, \mathrm{S}-$, and $\mathrm{C}$-compounds including nitrogen oxides $\left(\mathrm{NO}+\mathrm{NO}_{2}=\mathrm{NO}_{x}\right)$, sulfur dioxide $\left(\mathrm{SO}_{2}\right)$, and carbon monoxide $(\mathrm{CO})$, while ammonia $\left(\mathrm{NH}_{3}\right)$, a reduced $\mathrm{N}$-compound, is often neglected in urban air pollution monitoring and evaluation. Nevertheless, ammonia is the third most abundant $\mathrm{N}$-species (Perrino et al., 2002; Miller et al., 2014) and negatively affects ecosystems via dry deposition, contributing to exceedances of nitrogen critical loads in oligotrophic environments (Aneja et al., 2000; Sun et al., 2017). Moreover, ammonia plays a special role in atmospheric air pollution as the main alkaline gas that neutralizes acidic compounds in the troposphere (Perrino et al., 2002; Ferrara et al., 2012), leading to the formation 
of secondary PM (e.g., $\left.\left(\mathrm{NH}_{4}\right)_{2} \mathrm{SO}_{4}, \mathrm{NH}_{4} \mathrm{NO}_{3}\right)$ (Perrino et al., 2002), and enhancing the growth of existing particles (Baer et al., 2012; Sun et al., 2017; Wang et al., 2020). $\mathrm{SO}_{2}$ and $\mathrm{NO}_{2}$ are the key gas-phase precursors of the acidic compounds (e.g., $\mathrm{H}_{2} \mathrm{SO}_{4}, \mathrm{HNO}_{3}$ ) neutralized by ammonia and which are the primary components of secondary inorganic aerosols that dominate fine particle mass (e.g., Tsai et al., 2014). It is therefore essential to understand secondary inorganic aerosol formation from precursor gases, including $\mathrm{NH}_{3}$ (Tsai et al., 2014). Because of their low molecular weights, $\mathrm{NH}_{3}$ and $\mathrm{NH}_{4}{ }^{+}$have a more significant impact on molar-based aerosol chemical and optical properties than the same mass of nitrate $\left(\mathrm{NO}_{3}{ }^{-}\right)$, sulfate $\left(\mathrm{SO}_{4}{ }^{2-}\right.$ ) or organic compounds (Sun et al., 2017). $\mathrm{NH}_{3}$-based secondary aerosols like $\mathrm{NH}_{4} \mathrm{NO}_{3}$ are furthermore essential for the long-range transport of acidic pollutants due to the longer lifetime of ammonium salts in the atmosphere (1-15 days) compared to pure gaseous $\mathrm{NH}_{3}$ (few hours to few days) (Gordon, 1988; Aneja et al. 2000; Dammers et al., 2015). The main sources for $\mathrm{NH}_{3}$ at continental to global scales are animal waste and fertilizers from high-intensity agriculture (Perrino et al., 2002; Baer et al., 2012; Sun et al., 2017). In 32 member countries of the European Environment Agency (EEA), agriculture was responsible for over $90 \%$ of ammonia emissions into the atmosphere from 1990 to 2010 (EEA, 2010). Other sources are industries, biomass burning, humans, pets, wild animals, landfills and household products (Olivier et al., 1998; Sutton et al., 2000; Perrino et al., 2002). The city of Münster lies within one of the hotspot areas of high ammonia concentrations due to its location in the so-called "swine belt". This term describes the area of Northwest-Germany, Belgium and the Netherlands, where high-intensity animal husbandry of especially hog feeding is practiced. This leads to extremely high loads of local nitrogen deposition of 75 to $100 \mathrm{~kg} \mathrm{ha}^{-1} \mathrm{y}^{-1}$ in the Münsterland region, which lie above the mean $\mathrm{N}$ deposition for Germany (Frieling, 2014). The situation is similar for example to Taiwan (81\% from agriculture, livestock and biogenic sources, $1 \%$ from traffic) (Tsai et al., 2014), the North-China plain (88\% from fertilizer application and livestock waste) (Zhang et al. , 2018) and the U.S. (86\% from agricultural and natural sources, $8 \%$ from road traffic) (Livingston et al., 2009). The contribution from vehicles was assumed to be negligible until 1995 in the U.S. (Eggleston, 1992; Sutton et al., 1995; Perrino et al., 2002), after which an increase in $\mathrm{NH}_{3}$ traffic emissions occurred (Fraser and Cass, 1998; Moeckli et al., 1996; Perrino et al., 2002) in parallel to the increasing proportion of three-way catalytic converters (TWC) in gasoline vehicles from < 10\% of the vehicle fleet in 1981 to $>75 \%$ in 1993 in the U.S. (Kean et al., 2009). A similar pattern was observed for ammonia emissions from road transport in Italy after establishing TWCs (increase from < 1\% in 1993 up to > 4\% in 1999) (EEA, 2007). The $\mathrm{NH}_{3}$ emission factor (EF) of vehicles in the U.S. increased from $1.3 \pm 3.5 \mathrm{mg} \mathrm{km}^{-1}$ in 1981 (Pierson and Brachaczek, 1983) to $60 \mathrm{mg} \mathrm{km}^{-1}$ in 1993 (Fraser and Cass, 1998; Perrino et al., 2002). Ammonia is emitted as a byproduct during the operation of TWCs (Wang et al., 2019). A decreasing oxygen storage capacity of the catalyst caused by thermal aging in the TWC leads to overly reducing conditions in the catalyst and thereby increases the amount of produced $\mathrm{NH}_{3}$ in the exhaust gas stream (Bielaczyc et al., 2012). Besides TWCs, the selective catalytic reduction (SCR) systems of diesel vehicles have shown an increasing influence on ammonia emissions (Kean et al., 2009). SCR catalysts use an aqueous solution called diesel exhaust fluid (32.5\% urea, $67.5 \%$ deionized water) to convert $\mathrm{NO}_{\mathrm{x}}$ in the exhaust stream to $\mathrm{N}_{2}$ and water at temperatures between 150 and $350^{\circ} \mathrm{C}$ (formula (1)) (Boyce, 2012; Wang et al., 2019).

$4 \mathrm{NH}_{3}+2 \mathrm{NO}+2 \mathrm{NO}_{2}=4 \mathrm{~N}_{2}+6 \mathrm{H}_{2} \mathrm{O}$

To achieve this conversion the diesel exhaust fluid is permanently injected into the hot exhaust gas. The amount of diesel exhaust fluid is controlled by the vehicles' software. Multiple studies showed that this process is working best, i.e., with a high conversion efficiency of $65 \%$ to $90 \%$, under constant cruise speed and engine temperature (Boyce, 2012; Kim et al., 2012). These conditions are often not met under real-world urban driving conditions leading to excess emissions of $\mathrm{NO}_{x}, \mathrm{PM}$ and $\mathrm{NH}_{3}$ from diesel vehicles (Fu et al., 2013). The majority of diesel-fueled heavy-duty vehicles (HDVs) and light-duty vehicles (LDVs) in Europe was equipped with SCR catalysts from 2005 on (emission class Euro-IV) (Müller et al., 2003), followed by passenger cars in 2015 (emission class Euro-6) to meet the $\mathrm{NO}_{x}$ limits of the European Union (Emitec $\mathrm{GmbH}$, 2006). As a result of these developments, the traffic emissions of $\mathrm{NH}_{3}$ are now $57 \%$ of the $\mathrm{NO}_{x}$ emissions in Germany (EEA, 2007). There have been attempts to reduce ammonia emissions in 
Germany, but the actual decrease has been sparse (only 3\% in the period from 1993 to 2009) (Ferm and Hellsten, 2012). In contrast to $\mathrm{SO}_{2}$ or $\mathrm{NO}_{x}$, which both decreased in the last decades due to effective regulations, there are no vehicle emission standards for $\mathrm{NH}_{3}$ in Europe except the Euro-VI standard for diesel HDVs. Although ammoniated aerosols formed by secondary particle formation (SPF) are important for urban air quality, the emissions of their precursor gas ammonia are not well quantified or monitored (Sun et al., 2017). Overall, the uncertainties of global $\mathrm{NH}_{3}$ emissions are as large as $50 \%$ due to spatial and temporal variabilities and lack of in-situ measurement validation of emission inventories (Battye, 2003; Clarisse et al., 2009; Moravek et al., 2019). To account for the role of ammonia in the formation of fine PM, urban air pollution mitigation plans should also include reduction strategies for the primary precursor gas $\mathrm{NH}_{3}$ which will help reduce SPF (Hanson et al., 2002; Battye, 2003; McMurry et al., 2005; Livingston et al., 2009; Behera and Sharma, 2010; Benson et al., 2011; Miller et al., 2014). Attempts to monitor ammonia concentrations are often conducted at a low temporal resolution (Puchalski et al., 2011). To fully characterize temporal $\mathrm{NH}_{3}$ dynamics, measurements of ammonia with high temporal resolution are necessary (Battye, 2003; Nowak et al., 2007; Pinder et al., 2007; Miller et al., 2014).

Münster is a typical medium-sized German city ( 300,000 inhabitants) surrounded by intensive agricultural areas. This study aims 1 ) to identify ammonia emission sources at an urban site on different temporal scales from a few seconds to one day, 2) to evaluate the role of road traffic as an urban ammonia source using information from a real-world vehicle fleet combined with plume peak correlation of traffic-related trace gases with $\mathrm{NH}_{3}$ and 3 ) to evaluate the role of ammonia in SPF by evaluating the chemical composition of size-resolved PM samples. Our analysis is based on data from a field campaign that we conducted in summer 2018 on an arterial road in the city center. The site is representative for the exposure of the urban German population to air pollution.

\section{METHODS}

\subsection{Study Site}

We conducted an experimental campaign by operating a measurement container next to a two-lane street in the city center of Münster, Germany (51.9635 N, $7.6313 \mathrm{E}$ ) from 30/08/2018 through $31 / 10 / 2018$ (Fig. 1(a)). The road is an important East-West connection with a daily traffic volume of 33,700 vehicles and lies within a narrow street canyon with buildings of approximately nine to twelve meters height (height-to-width ratio $\sim 0.56-0.75)$. The upper speed limit for road traffic was $30 \mathrm{~km} \mathrm{~h}^{-1}$. A major local and regional bus station is located about $75 \mathrm{~m}$ to the NW, and a T-intersection with traffic lights is located about $60 \mathrm{~m}$ to the SE. The bus station is served by 19 public bus lines (Stadtwerke Münster, 2016b). The wind was channelled in the NW-SE direction by the street canyon (Fig. 1(b)). Mean wind speed was $1.0 \mathrm{~m} \mathrm{~s}^{-1}$ and the mean temperature was $20.7^{\circ} \mathrm{C}$ during the nine-week measurement period.

$\mathrm{NO}_{2}$ is regularly monitored by the environmental protection agency of the federal state of North Rhine-Westphalia (LANUV NRW) by using passive samplers, which were about $18 \mathrm{~m}$ away from the measurement container (station code: VMSB). Annual average $\mathrm{NO}_{2}$ concentration at the nearby air quality monitoring station (station code: VMSB) was $34.1 \mu \mathrm{g} \mathrm{m}^{-3}$ in 2018 (LANUV NRW, 2019). $\mathrm{PM}_{10}$ and $\mathrm{NO}_{\mathrm{x}}$ are also monitored continuously by the LANUV NRW at the "Münster Weseler Straße" Station (station code: VMS2) $1.4 \mathrm{~km}$ beeline SW of the measurement container.

Münster is surrounded by intensively used agricultural areas, the nearest fields being located only $2.5 \mathrm{~km}$ beeline from the measurement container in the city center. Agriculture dominates the landscape outside the city (66\% of the total area) (Lammers and Becker, 2014). The main crops are corn and several cereals ( $88 \%$ of total crops), which are both mostly used for animal husbandry (dairy farms, hog feeding, poultry farming) (Lammers and Becker, 2014).

\subsection{Sampling}

We collected meteorological and air pollution data on top of the measurement container. The sensors and sample inlets of wind speed and wind direction, air temperature, relative humidity $(\mathrm{rH}), \mathrm{CO}_{2}, \mathrm{H}_{2} \mathrm{O}, \mathrm{NO}_{x}, \mathrm{O}_{3}, \mathrm{NH}_{3}$ and $\mathrm{PM}$ with diameters between $0.006 \mu \mathrm{m}$ to $10 \mu \mathrm{m}\left(\mathrm{PM}_{10}\right)$ were located on top of the measurement container (horizontal distance to street: $0.3 \mathrm{~m}$, height above ground: $4 \mathrm{~m}$ ) (Table 1). The measurement frequency was $10 \mathrm{~Hz}$, except for the ammonia instrument 

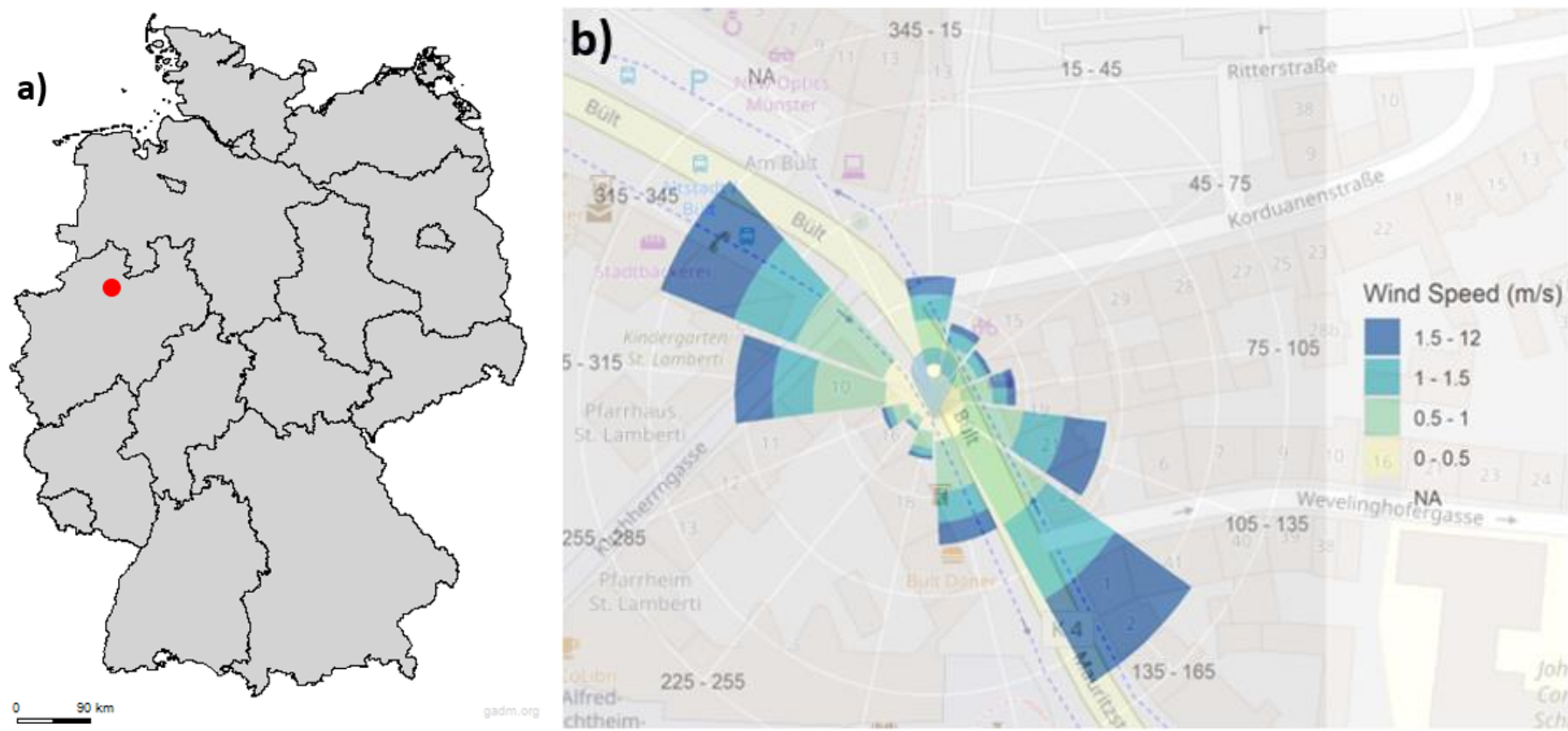

Fig. 1. (a) Map of Germany with borders of federal states. The city of Münster, North-Rhine Westphalia, is marked with a red point. (b) Detailed map of the measurement site located in a narrow street canyon. The location of the measurement container is indicated by the blue marker (source: Open Street Map). As a transparent overlay one can see the wind rose during the measurement campaign.

Table 1. Overview over all sensors used during the measurement campaign with the respective detection method and time resolution. The D50\% separation diameters of the ELPI+ are $0.006,0.017,0.030,0.060,0.108,0.17,0.26,0.40,0.64,1.0,1.6,2.5$, $4.4,6.8$ and $10 \mu \mathrm{m}$, respectively.

\begin{tabular}{lllll}
\hline Instrument & Parameter & Measurement technique & $\begin{array}{l}\text { Time } \\
\text { resolution }\end{array}$ & $\begin{array}{c}\text { Height } \\
{[\mathrm{m}]}\end{array}$ \\
\hline Gill RS3-50 & $\begin{array}{l}\text { Wind speed, wind direction, sonic } \\
\text { temperature }\end{array}$ & 3-D ultrasonic anemometer & $10 \mathrm{~Hz}$ & 4.40 \\
LI-COR LI-7500A & $\mathrm{CO}_{2}, \mathrm{H}_{2} \mathrm{O}$ & Open-path NDIR gas analyzer & $10 \mathrm{~Hz}$ & 4.34 \\
ECO PHYSICS CLD 899 Y & $\mathrm{NO}_{2} \mathrm{NO}_{2}$ & Chemiluminescence & $10 \mathrm{~Hz}$ & 4.04 \\
ECO PHYSICS CLD 88 & $\mathrm{O}_{3}$ & Chemiluminescence & $10 \mathrm{~Hz}$ & 4.03 \\
Teledyne M501E & $\mathrm{NH}_{3}, \mathrm{NO}, \mathrm{NO}_{2}$ & Chemiluminescence & $0.2 \mathrm{~Hz}$ & 3.78 \\
Dekati ELPI+ & $\mathrm{PMC}$, PNC for 14 size fractions & Electrical low-pressure impactor & $10 \mathrm{~Hz}$ & 3.96 \\
Campbell Scientific HC2-S3 & Air temperature, rH & Resistance thermometer & $1 \mathrm{~min}$ & 3.54 \\
\hline
\end{tabular}

$(0.2 \mathrm{~Hz}) . \mathrm{CO}_{2}$ was quantified by measuring the absorptance of its molecules in the infrared spectrum over the open path of the LI-COR sensor head (sample column) (LI-COR Inc., 2009). The sensor head emits in the infrared spectrum and measures the remaining light intensity after the absorption by $\mathrm{CO}_{2}$ molecules in the sample path at the detector unit. The more $\mathrm{CO}_{2}$ is present in the sample path, the weaker is the detected infrared radiation signal at the detector unit. Ammonia was detected via the chemiluminescence technique, where $\mathrm{NH}_{3}$ is oxidized into $\mathrm{NO}$ in a high-temperature catalytic converter at a temperature of $825^{\circ} \mathrm{C}$ and then the resulting NO is measured via by the chemiluminescent reaction with ozone at the detector unit (TAPI, 2012). To avoid a delayed or modified $\mathrm{NH}_{3}$ signal, a stainless-steel tubing with a length of $1.3 \mathrm{~m}$, permanently heated to $40^{\circ} \mathrm{C}$, was employed. The Teledyne chemiluminescence detector was operated without a particulate filter to avoid adsorption and desorption from the filter depending on temperature and relative humidity. Due to the filter-less sampling setup $\mathrm{NH}_{4}{ }^{+}$may contribute to the measured ammonia. The gas-to-particle-conversion ratio of ammonium and ammonia indicates that during the day, $\mathrm{NH}_{3}$ is the major component, while during the night particulate $\mathrm{NH}_{4}^{+}$might also play a role. The high daytime temperatures during the measurement campaign probably lead to reliable 
measurements of $\mathrm{NH}_{3}$ (Xu et al., 2020). The effective time response of the system was $4 \mathrm{~s}$. This time delay was removed in post-processing using cross-correlation with $\mathrm{CO}_{2}$ as a traffic tracer. For $\mathrm{NO}_{x}$ and $\mathrm{O}_{3}$, ambient air was sampled through thermally insulated PTFE tubing with $4.5 \mathrm{~m}$ and 3.9 m length, respectively. $\mathrm{PM}_{10}$ was collected with a Tygon tubing of $5 \mathrm{~m}$ length with an inner diameter of $10.5 \mathrm{~mm}$ at a flow rate of $10.5 \mathrm{~L} \mathrm{~min}^{-1}$. PM samples (diameters: $0.05 \mu \mathrm{m}-10 \mu \mathrm{m}$ ) were additionally collected with a five-stage-Berner impactor between 16/10/2018 and 23/10/2018 for 10 hours per day. PM was sampled on Tedlar foils for later inorganic ion analysis. As a measure for atmospheric static stability the stability parameter $\zeta$ was calculated using the meteorological data of the "Steinfurter Str." Station, which is operated by our research group, located $2.6 \mathrm{~km}$ beeline NW of the measurement container.

\subsection{Traffic Detection}

Automatic Number Plate Recognition (ANPR) cameras (model Long Range 25-1) (uniserve GmbH, Meschede, Germany) were installed at the measurement container to collect highly-resolved information on traffic density and vehicle characteristics. Video surveillance in public spaces was approved by the responsible data security officer in advance of this scientific study and in accordance with the EU data protection directive. Two cameras were orientated on one traffic lane each. During the nine weeks of measurements, a total of 841,568 vehicles were recorded. By license plate identification, information on vehicle type, engine type, European emission class, $\mathrm{CO}_{2}$ emissions per km, etc. was obtained from the German Central Vehicle Register managed by the Federal Motor Transport Authority (Kraftfahrtbundesamt). For $6 \%$ of the recorded license plates, no vehicle characteristics were available either because they were from a foreign country or because the ANPR was faulty. Additionally, a microphone recorded the sound volume in the street canyon to test sound as a traffic indicator (Goulier et al., 2020).

\subsection{Data Processing and Time Series Analysis}

A time series of 49 days of $0.2 \mathrm{~Hz}$ data was available for $\mathrm{NH}_{3}$ with $86 \%$ of the data remaining for analysis after quality assessment and quality control (QA/QC). The $10 \mathrm{~Hz}$ data were available for a time series of 59 days, of which $99.3 \%, 96.7 \%, 96.6 \%, 77.4 \%, 73.4 \%$ and $97.4 \%$ passed the $\mathrm{QA} / \mathrm{QC}$ procedure for the anemometer, $\mathrm{CO}_{2}, \mathrm{H}_{2} \mathrm{O}, \mathrm{NO}_{\mathrm{x}}, \mathrm{O}_{3}$ and $\mathrm{PM}_{10}$ data, respectively. All statistical computation and peak detection was performed with the open-source $\mathrm{R}$ version 3.5.1 (R Core Team, 2019) using the R-packages "openair" (Carslaw and Ropkins, 2012), "devtools" (Wickham et al., 2020), "ggplot2" (Wickham, 2009), "gridExtra" (Baptiste, 2017), "stringi" (Gagolewski, 2020), "stringr" (Wickham, 2019), "data.table" (Dowle and Srinivasan, 2019), "padr" (Thoen, 2019), "egg" (Baptiste, 2019), "cowplot" (Wilke, 2019) and “OpenStreetMap" (Fellows and Stotz, 2019).

\subsection{Peak Integration and Detection}

Emissions from passing vehicles were detected as a peak of the respective air pollutants at the measurement site. The time lags caused by the tubing of enclosed-path sensors were quantified and eliminated by cross-correlation with the $\mathrm{CO}_{2}$ concentration (time lag for $\mathrm{NO}_{x}, \mathrm{O}_{3}$ and $\mathrm{PM}$ were $3.6 \mathrm{~s}, 3.0 \mathrm{~s}$ and $4.0 \mathrm{~s}$, respectively). Peak analysis of the data set was performed using the semi-empirical, automatic peak detection method of (Peitzmeier et al., 2017). We assumed that each peak was caused by either an exhaust plume of a single vehicle or a combined exhaust plume. Peak integrals of all parameters were referenced to the simultaneously occurring peaks of $\mathrm{CO}_{2}$. Peaks were defined as local maxima of the data record, for which 50 neighbouring points both prior and after the maximum were found. A total of 149,484 peaks were detected for $\mathrm{CO}_{2}$, and the mean peak duration was $8.3 \mathrm{~s}$ (median: $6.3 \mathrm{~s}$ ). The baseline for $\mathrm{CO}_{2}$ was a moving median of 599 data points ( $1 \mathrm{~min}$ ) with a moving standard deviation (SD) of 6000 data points (10 $\mathrm{min}$ ) (Fig. 2). A moving average of 20 data points was calculated as the peakline (PL) following shortterm variations of the $\mathrm{CO}_{2}$ concentrations. The $\mathrm{PL}$ for $\mathrm{NH}_{3}$ was calculated by a moving average of 12 data points ( $1 \mathrm{~min}$ ) and the baseline with a moving median of 120 data points (10 min). When the baseline and the PL intersected, the segment of the time series was identified as a peak interval and the area of each pollutant was integrated for each peak interval. The integrated peak intervals were then used to compute the peak ratios of the respective component to $\mathrm{CO}_{2}$. The concentrations of exhaust gases emitted by traffic will generally decrease with increasing 


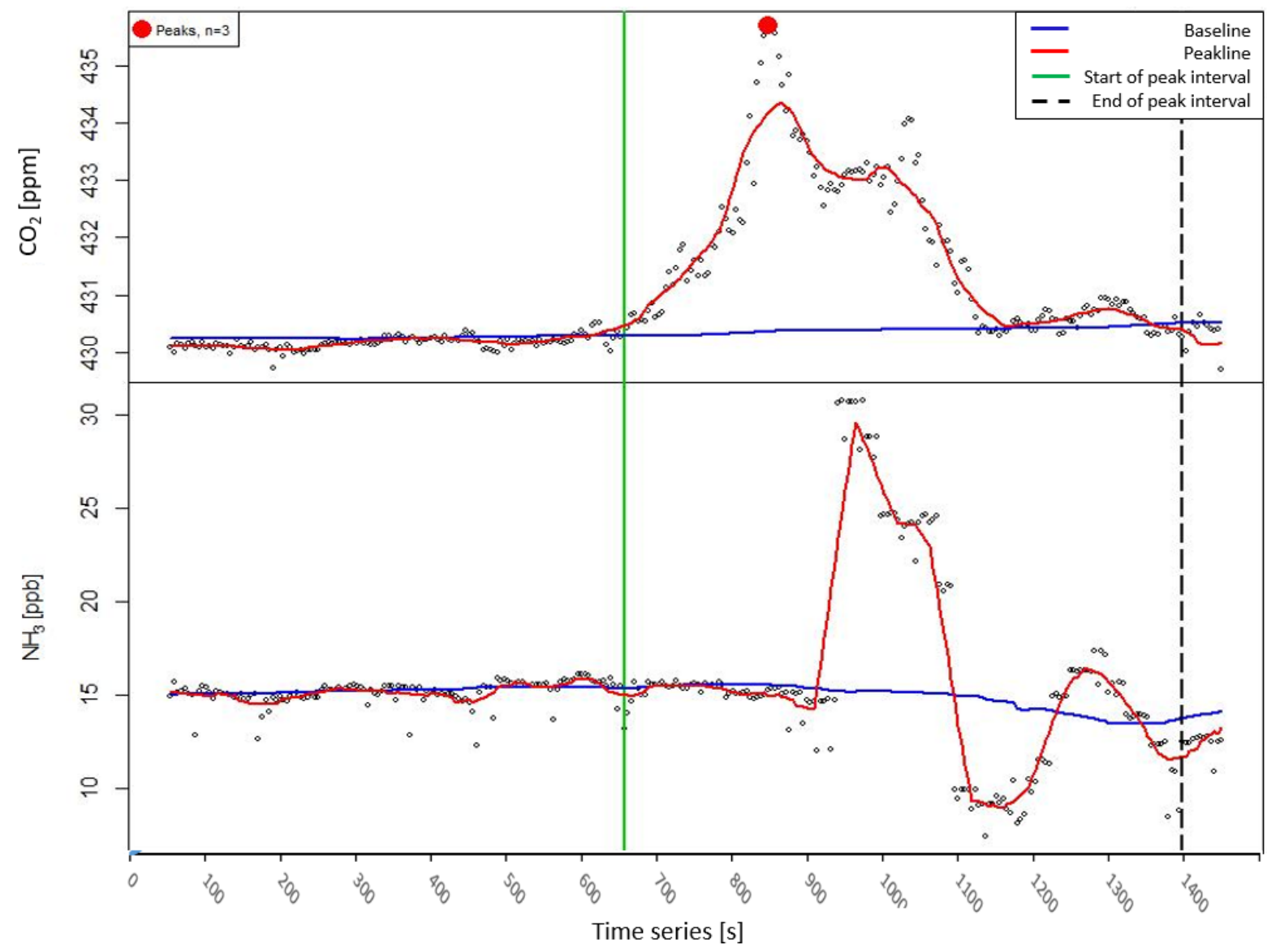

Fig. 2. Baselines (blue) and peaklines (red) of $\mathrm{CO}_{2}$ (top panel) and $\mathrm{NH}_{3}$ (bottom panel) for an example period of 1500 data points. The vertical green line represents the start of a peak and the vertical dashed black line indicates the end of a peak with the peak interval between the green and black line. The red point indicates an identified $\mathrm{CO}_{2}$ peak, which was $\geq 3 \mathrm{ppm}$.

distance from the source, but due to slow chemical reactions the ratio of the measured compounds will remain rather constant within a time period of several minutes to hours. Therefore, it is plausible to assume that the peak pollutant ratios measured at the measurement site are representative for the composition of exhaust plumes within the street canyon.

\subsection{Handbook Emission Factors for Road Transport (HBEFA)}

The HBEFA is a European database covering temperature-dependent emission factors for common vehicle types and traffic situations (Matzer et al., 2019). Real-world emission measurements are used to model warm and cold start emissions depending on vehicle segment and traffic situation. The predicted emission factors of $\mathrm{CO}_{2}, \mathrm{CO}_{2}$ equivalents $\left(\mathrm{CO}_{2} \mathrm{e}\right), \mathrm{NH}_{3}, \mathrm{NO}_{\mathrm{x}}, \mathrm{NO}_{2}, \mathrm{CO}, \mathrm{CH}_{4}$, $\mathrm{HC}, \mathrm{NMHC}, \mathrm{PM}_{10}$ (for exhaust and non-exhaust), $\mathrm{PM}_{2.5}$ (for exhaust and non-exhaust), particle number concentration for $\mathrm{PM}_{10}\left(\mathrm{PN}_{10}\right), \mathrm{BC}$ (for exhaust and non-exhaust) and $\mathrm{SO}_{2}$ were computed for a comparable inner-city, stop-\&-go traffic situation with a speed limit of $30 \mathrm{~km} \mathrm{~h}^{-1}$, a typical German vehicle fleet composition, mean monthly temperatures for 2018 in Germany and an inclination of $<2 \%$ of the area. To compare the real-world ERs of road traffic with the theoretical emission ratios predicted by the HBEFA database, the air pollutant data and the traffic data were merged by timestamp. Therefore, each plume of air pollutants could be assigned to the respective vehicles that passed by the container during the same time period.

\subsection{Chemical Analysis of Fine Particles}

Fine particles collected with the five-stage Berner cascade impactor (stage 1: 0.05-0.14 $\mu \mathrm{m}$, stage 2: $0.14-0.42 \mu \mathrm{m}$, stage 3: $0.42-1.2 \mu \mathrm{m}$, stage $4: 1.2-3.5 \mu \mathrm{m}$, stage $5: 3.5-10 \mu \mathrm{m}$ ) were analyzed for their concentration of sulfate, chloride, nitrate and ammonium. The sample foils 
were inserted into $50 \mathrm{ml}$ vials and kept dry and frozen at $-20^{\circ} \mathrm{C}$ until analysis. For the analysis, $10 \mathrm{~mL}$ of distilled water was added to each vial to extract the PM from the foils. The extracts were shaken for $1 \mathrm{~h}$ with 200 Mot $\mathrm{min}^{-1}$ and then ultrasonicated for another $1 \mathrm{~h}$. Afterwards, each sample was filtered through a $0.22 \mu \mathrm{m}$ pore size filter (Simplepure, $\mathrm{NY}+\mathrm{GF}, 0.22 \mu \mathrm{m}$ ). $\mathrm{NH}_{4}{ }^{+}$was analyzed with a continuous flow analyzer (Skalar, San++ Automated Wet Chemistry Analyzer) with a detection limit of $0.2 \mathrm{mg} \mathrm{L}^{-1}$, and the concentrations of inorganic anions were measured using ion chromatography (Metrohm, 883 Basic IC plus) with a detection limit $0.5 \mathrm{mg} \mathrm{L}^{-1}$.

\section{RESULTS AND DISCUSSION}

\subsection{Peak Ratios of Air Pollutants in Exhaust Plumes from Road Traffic}

The median peak ratios of $\mathrm{NH}_{3} / \mathrm{CO}_{2}, \mathrm{NO} \times \mathrm{CO}_{2}, \mathrm{PM}_{10} / \mathrm{CO}_{2}$ and $\mathrm{PN}_{10} / \mathrm{CO}_{2}$ were calculated for synchronously detected peak intervals (Table 2 ). The overall median peak $\mathrm{NH}_{3} / \mathrm{CO}_{2}$ ratio was $6.11 \times 10^{-5}$, while the overall median peak $\mathrm{NO}_{x} / \mathrm{CO}_{2}$ ratio was $2.61 \times 10^{-3}$ (Table 3 ). Thus, 43 times more $\mathrm{NO}_{x}$ was emitted per $\mathrm{g} \mathrm{CO}_{2}$ as compared to $\mathrm{NH}_{3}$. The mass fraction of ammonia that is present in the vehicles' exhaust gas is apparently small compared to that of $\mathrm{NO}_{x}$. For $\mathrm{PM}_{10} / \mathrm{CO}_{2}$ the median peak ratio $\left(1.62 \times 10^{-5}\right)$ was $26 \%$ of the median peak $\mathrm{NH}_{3} / \mathrm{CO}_{2}$ ratio. The $\mathrm{PN}_{10} / \mathrm{CO}_{2}$ ratio was $38829 \mathrm{p} \mathrm{g}^{-1}$. The real-world (i.e., the in-situ measured variability during the measurement campaign) median peak $\mathrm{NH}_{3} / \mathrm{CO}_{2}$ ratio was $30 \%$ lower than the median peak $\mathrm{NH}_{3} / \mathrm{CO}_{2}$ emission ratio of HBEFA $\left(8.70 \times 10^{-5}\right.$ ) (Table 3$)$. In addition, the variability of the real-world ammonia peak ratio was high compared to the HBEFA predictions for $\mathrm{NH}_{3} / \mathrm{CO}_{2}$ (Fig. 3). The interquartile range of the real-world $\mathrm{NH}_{3} / \mathrm{CO}_{2}$ ratio was larger, but the median lower compared to the HBEFA median peak $\mathrm{NH}_{3} / \mathrm{CO}_{2}$ emission ratio. This indicates that the $\mathrm{NH}_{3}$ emissions were distributed heterogeneously across the vehicle fleet in this study, where some vehicles caused very high short-term peaks of the $\mathrm{NH}_{3}$ mixing ratio up to $216 \mathrm{ppb}$ in the exhaust plumes, while other vehicles likely emitted much less or no ammonia at all. In a tunnel study in California, U.S., mainly light-duty vehicles (LDV) were responsible for traffic-related ammonia emissions, while heavy diesel trucks played only a minor role (Kean et al., 2009). This was also likely the case at our study site, as the vehicle fleet during the measurement campaign consisted mainly of passenger cars and LDVs (91\%) (Fig. 4). Busses and HDVs only make up for $6 \%$ and $3 \%$ of local road traffic, respectively (Fig. 4). They may be responsible for single $\mathrm{NH}_{3}$ peaks, but overall their influence on traffic-related ammonia emissions are probably low. The second main factor influencing the amount of vehicleemitted ammonia is the fuel type. Ammonia is mainly emitted by diesel vehicles due to selective catalytic reduction catalysts, which are used to clean the exhaust gas from $\mathrm{NO}_{\mathrm{x}}$ using an urea solution (Eq. (1)) (Zhang and Wang, 2015). This reaction requires constant temperatures within

Table 2. Number of detected positive peak ratios of $\mathrm{NH}_{3} / \mathrm{CO}_{2}, \mathrm{NO}_{\mathrm{x}} / \mathrm{CO}_{2}, \mathrm{PM}_{10} / \mathrm{CO}_{2}$ and $\mathrm{PN}_{10} / \mathrm{CO}_{2}$ for the measurement campaign, respectively.

\begin{tabular}{ll}
\hline Peak ratio $\left[\mathrm{g} \mathrm{g}^{-1}\right]$ & Nr. peak intervals $[-]$ \\
\hline $\mathrm{NH}_{3} / \mathrm{CO}_{2}$ & 1784 \\
$\mathrm{NO}_{x} / \mathrm{CO}_{2}$ & 88428 \\
$\mathrm{PM}_{10} / \mathrm{CO}_{2}$ & 40456 \\
$\mathrm{PN}_{10} / \mathrm{CO}_{2}$ & 36898 \\
\hline
\end{tabular}

Table 3. Median peak emission ratios of the detected peak intervals of $\mathrm{NH}_{3} / \mathrm{CO}_{2}\left[\mathrm{~g} \mathrm{~g}^{-1}\right], \mathrm{NO}_{\times} / \mathrm{CO}_{2}$ [ $\mathrm{g} \mathrm{g}^{-1}$ ] $\mathrm{PM}_{10} / \mathrm{CO}_{2}\left[\mathrm{~g} \mathrm{~g}^{-1}\right]$ and $\mathrm{PN}_{10} / \mathrm{CO}_{2}\left[\mathrm{p} \mathrm{g}^{-1}\right]$ for the measurement campaign and the HBEFA database, respectively.

\begin{tabular}{lll}
\hline Parameter & HBEFA & Real-world \\
\hline $\mathrm{NH}_{3} / \mathrm{CO}_{2}$ & $8.70 \times 10^{-5}$ & $6.11 \times 10^{-5}$ \\
$\mathrm{NO}_{\times} / \mathrm{CO}_{2}$ & $4.06 \times 10^{-4}$ & $2.61 \times 10^{-3}$ \\
$\mathrm{PM}_{10} / \mathrm{CO}_{2}$ & $8.04 \times 10^{-6}$ & $1.62 \times 10^{-5}$ \\
$\mathrm{PN}_{10} / \mathrm{CO}_{2}$ & 5252701539 & 38829 \\
\hline
\end{tabular}



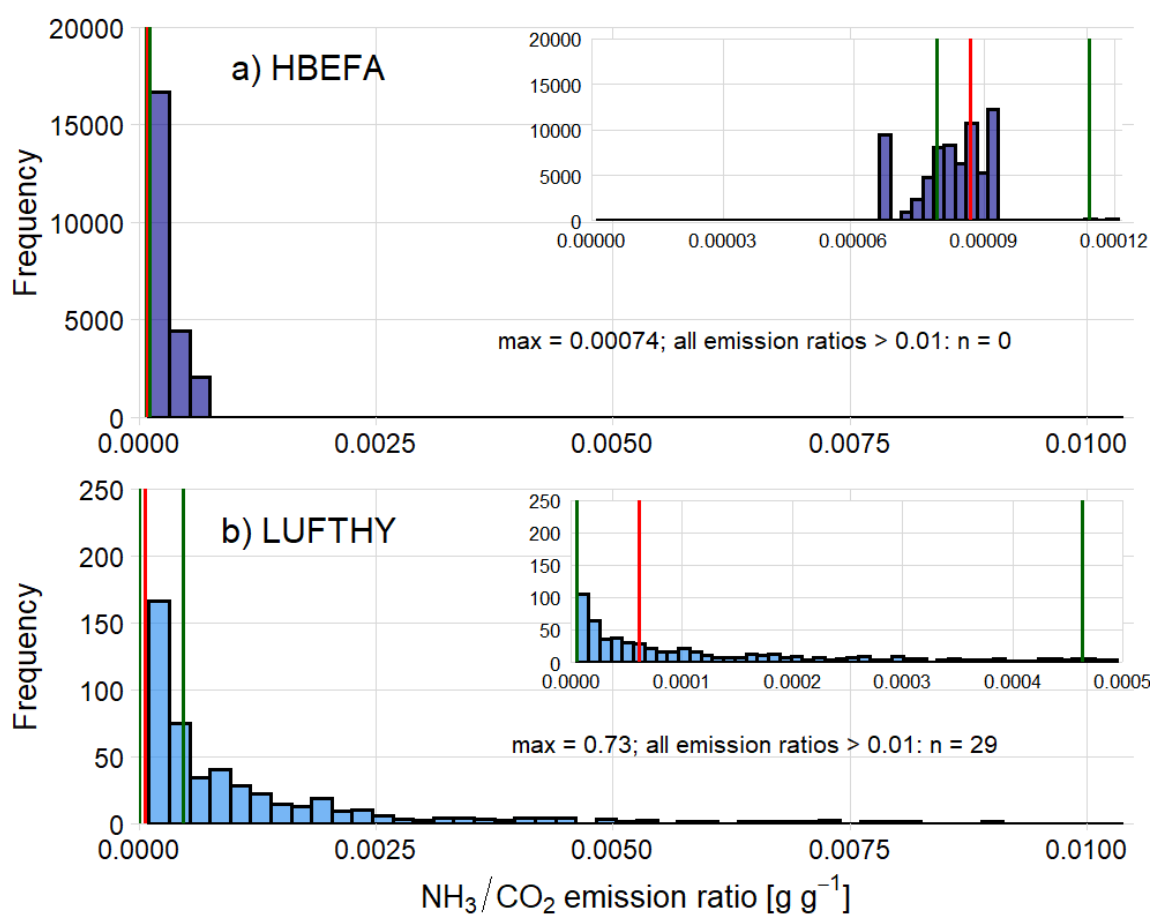

Fig. 3. Median peak $\mathrm{NH}_{3} / \mathrm{CO}_{2}$ ratios for the theoretical predictions of the HBEFA (a) and for the measurement campaign (b) based on the local vehicle fleet. Each inlet subplot shows the interquartile ranges of the respective $\mathrm{NH}_{3} / \mathrm{CO}_{2}$ ratios. The vertical dark green lines represent the $1^{\text {st }}$ and $3^{\text {rd }}$ interquartile range limits and the vertical red line indicates the median value of the real-world $\mathrm{NH}_{3} / \mathrm{CO}_{2}$ ratio and the $\mathrm{HBEFA} \mathrm{NH} / \mathrm{CO}_{2}$ emission ratio.

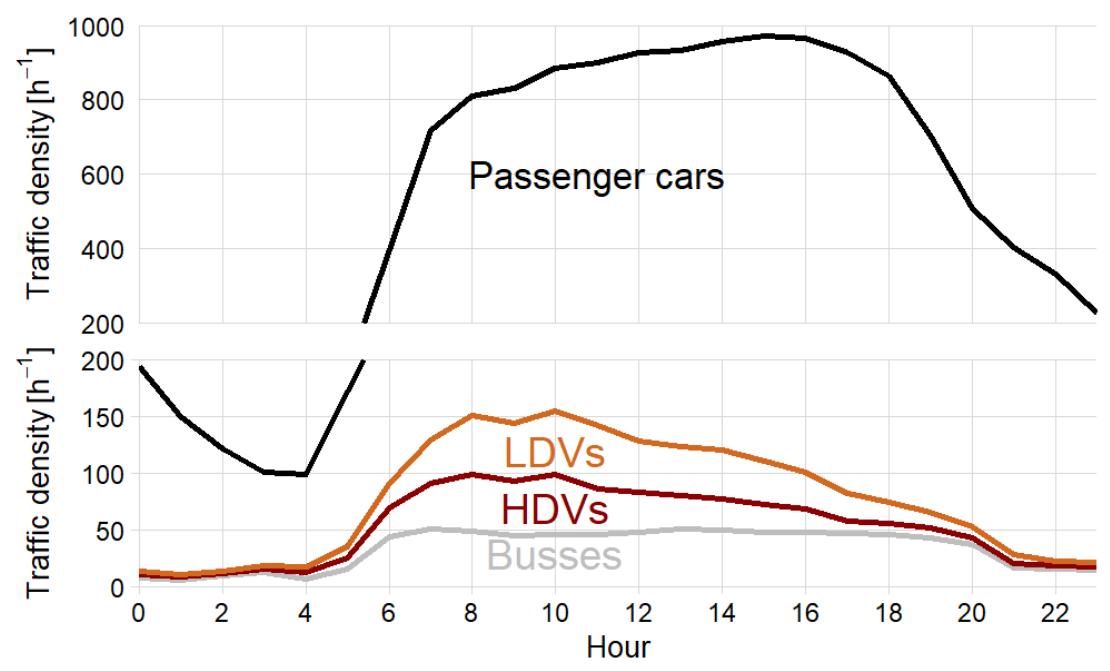

Fig. 4. Mean diurnal cycle of the vehicle types during the campaign. The curves of busses (beneath the grey line), HDVs (beneath the dark red line), LDVs (beneath the orange line) and passenger cars (beneath the black line) are additive summing up to the overall traffic density (black line). Please note that the $y$-axis is broken with a different $y$-axis scaling for the upper and bottom panel to show the patterns of HDVs, LDVs and busses despite their small share on the overall traffic density.

the catalyst and an adjusted amount of injected urea solution. Both requirements are often not met during urban driving conditions with frequently changing cruising speeds and cold-started engines. Additionally, the tanks containing the diesel exhaust fluid are often designed too small to provide an adequate amount on long-term operation. Moreover, vehicle manufacturers 
manipulated the vehicles' software to reduce the use of diesel exhaust fluid in order to decrease vehicle weight and avoid the need of frequent refills of the urea solution. So, the vehicles with so-called 'defeat devices' only met the air pollution restrictions on the test bench, but not under real-world driving conditions. The shutdown of SCR catalysts leads to less emissions of $\mathrm{NH}_{3}$, but increased emissions of nitrogen oxides from the respective vehicles. This incident became known as the Dieselgate scandal in 2015 and was one of the greatest intentional deceptions of consumers so far (Bovens, 2016). In Europe, 8.5 Mio. vehicles had manipulated SCR catalysts of the manufacturer "Volkswagen" (VW), of which 2.5 Mio. were registered in Germany (BMVI, 2016). In our study, vehicles with SCR catalysts make up $19 \%$ of the vehicle fleet. TWC systems of gasoline vehicles also emit $\mathrm{NH}_{3}$ if the catalyst is thermally aged. Hybrid vehicles are promoted as an environmental-friendly alternative to conventional fuels, but depending on the fuel used, they can also contribute significantly to traffic-related ammonia emissions. A hybrid vehicle with a TWC was shown to emit $93 \%$ more ammonia when it was operated with gasoline compared to Compressed Natural Gas (CNG) as an alternative power source, while another vehicle emitted $2 \%$ more $\mathrm{NH}_{3}$ when fueled with liquefied petroleum gas (LPG) (Bielaczyc et al., 2012). Besides vehicle type, also the driving patterns can significantly influence $\mathrm{NH}_{3}$ emissions. Several dynamometer laboratory studies have revealed that ammonia emissions were highest during acceleration events of modern vehicles (Huai et al., 2003, 2005). Bielaczyc et al. (2012) also found a correlation between engine power and ammonia emissions. Therefore, it is likely that high short-term $\mathrm{NH}_{3}$ emissions occurred during the typical urban stop and go traffic.

The peak detection method by Peitzmeier et al. (2017) proved to be valuable to estimate realworld peak ratios of $\mathrm{NH}_{3} / \mathrm{CO}_{2}, \mathrm{NO}_{x} / \mathrm{CO}_{2}, \mathrm{PM}_{10} / \mathrm{CO}_{2}$ and $\mathrm{PN}_{10} / \mathrm{CO}_{2}$. Nevertheless, the method has some limitations. The respective second air pollutant $\left(\mathrm{NH}_{3}, \mathrm{NO}_{x}, \mathrm{PM}_{10}, \mathrm{PN}_{10}\right)$ has to peak in the same peak interval as $\mathrm{CO}_{2}$ or it will not be detected and thus no peak ratio will be calculated. $\mathrm{A}$ given exhaust plume may reach the open-path $\mathrm{CO}_{2}$ analyzer, but not the inlet for the other analyzers $\left(\mathrm{NH}_{3}, \mathrm{NO}_{x}, \mathrm{PM}\right)$, although the distance between them was small $(56 \mathrm{~cm}, 30 \mathrm{~cm}, 38 \mathrm{~cm})$. Also, the vehicles' exhaust plumes may mix on their way to the sensor inlets leading to indistinctive peak signals representing a number of vehicles rather than a single one. In addition, a certain fraction of plumes may not have been detected at all as they did not pass the instruments' inlets due to meteorological conditions (adverse wind direction, etc.). In consequence, there is a considerable uncertainty in the peak assignment to vehicles. On the other hand, it is the sheer number of analyzed peaks $\left(149,484 \mathrm{CO}_{2}\right.$ peaks) populating the emission dataset that yielded statistically robust and overall reliable data.

\subsection{Source Apportionment of $\mathrm{NH}_{3}$ in the Urban Atmosphere}

The $\mathrm{NH}_{3}$ mixing ratios in an urban street canyon in Münster, NW Germany, during the measurement campaign were rather large (mean: $17 \mathrm{ppb}$, median: $15 \mathrm{ppb}$ ) compared to those found in other studies, for instance with averages ranging from $1.1 \mathrm{ppb}$ in Houston, U.S. (Nowak et al., 2010) to $12 \mathrm{ppb}$ in Seoul, Korea (Phan et al., 2013). The $\mathrm{NH}_{3}$ mixing ratio at road level during our study (median: $15 \mathrm{ppb}$ ) was furthermore three-times higher than the ammonia mixing ratio measured in Münster at a rooftop upwind of the city center in 2005 (median: 5.2 ppb) (Vogt et al., 2005). This indicates that emissions from motorized road traffic contribute significantly to $\mathrm{NH}_{3}$ at our urban study site, in addition to those of the intensively cultivated agricultural areas that surround the city (Vog et al., 2005). Note that chemical and physical processes such as nucleation, volatilization and wet and dry deposition lead to a complex temporal pattern of $\mathrm{NH}_{3}$ responding to emissions, wind direction, wind speed, temperature, $\mathrm{rH}$ as well as boundary layer (BL) dynamics. The mean diurnal cycle of the ammonia mixing ratio showed a distinct diel course with a maximum at 1000 and a daily amplitude of $9 \mathrm{ppb}$ (Fig. 5). It is striking that this late morning maximum was not synchronous with the increase of traffic nor with the peaks of the other trace gases and particles. $\mathrm{CO}_{2}$ and $\mathrm{NO}_{\mathrm{x}}$, but also $\mathrm{PM}_{10}$ and $\mathrm{PN}_{10}$ begin increasing early in the morning at 0600 and reach their maxima at 0800 (Fig. 5). After the steep increase during morning rush hour, $\mathrm{CO}_{2}, \mathrm{NO}_{\mathrm{x}}, \mathrm{PM}_{10}$ and $\mathrm{PN}_{10}$ decrease after 0800 , although the traffic density kept increasing slightly until 1700. After a stable atmospheric $B L$ during the night, the new daily mixed layer developed after 0800. At the same time, the $\mathrm{NO}_{x}, \mathrm{CO}_{2}, \mathrm{PM}_{10}$ and $\mathrm{PN} 10$ mixing ratios and concentrations begin to decrease as less polluted air is entrained into the mixed layer from above. Meanwhile, $\mathrm{NH}_{3}$ also increases and reaches its peak mixing ratio at 1000 , when the $\mathrm{BL}$ is least stable with a 

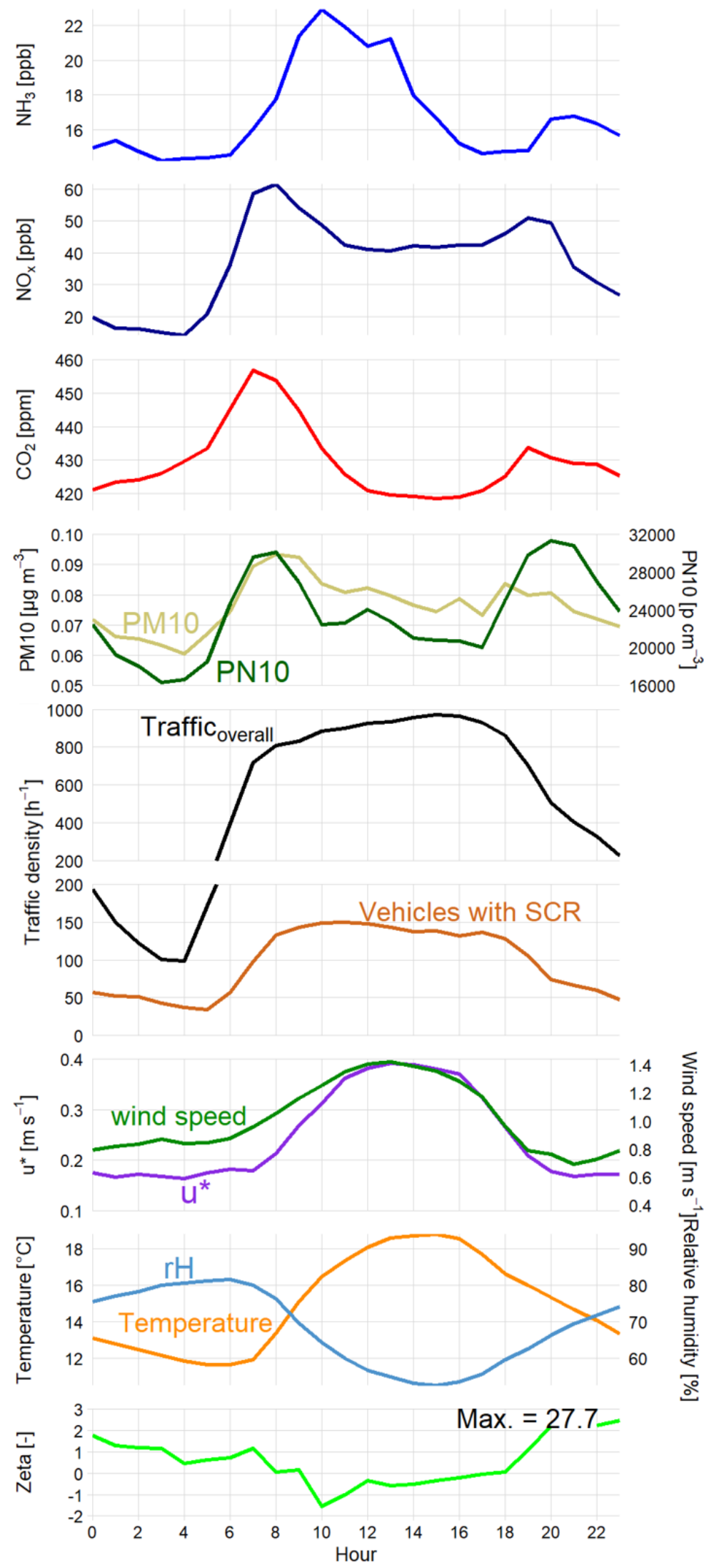

Fig. 5. Mean diurnal cycle of $\mathrm{NH}_{3}, \mathrm{CO}_{2}, \mathrm{NO}_{x}, \mathrm{PM}_{10}, \mathrm{PN}_{10}$, traffic density, wind speed, friction velocity $\mathrm{u}^{*}$ and stability parameter zeta $\zeta$. Please note that the $\mathrm{y}$-axis for the traffic density plot is broken with a different $y$-axis scaling for the upper and bottom panel to show the patterns of overall road traffic and vehicles with SCR-catalysts despite their small share on the overall traffic density. 
stability parameter $\zeta$ of -1.57 . A plausible explanation could be that ammonia had not been homogeneously mixed within the nocturnal residual layer, but was enriched in its upper parts. As soon as the atmospheric conditions transitioned from stable to neutral and unstable (08001000 ), the accumulated $\mathrm{NH}_{3}$ caused the midday peak after getting entrained into the mixed layer. This process is a good explanation for the observed diurnal pattern of $\mathrm{NH}_{3}$ and indicated that ammonia must have its origin outside the city, in the agricultural surroundings of Münster. There was also an increase of SCR-equipped vehicles in the late morning hours (Fig. 4), but the percentage of these vehicle on the overall traffic volume is so low that their contribution to overall ammonia emissions is likely to be only of minor importance.

It is surprising, though, that the high $\mathrm{NH}_{3}$ mixing ratio did not persist after 1000 . The rather rapid decrease of ammonia mixing ratio in the afternoon may have been caused by removal or dilution of $\mathrm{NH}_{3}$ in the mixed layer. The concentrations of all traffic-related air pollutants and of $\mathrm{NH}_{3}$ decreased during the afternoon until 1800 as the mixing layer further developed, although the traffic intensity stayed high throughout this period (Fig. 5). After the stabilization of the BL at 1800, the respective concentrations picked up again. $\mathrm{NH}_{3}, \mathrm{NO}_{x}, \mathrm{CO}_{2}, \mathrm{PM}_{10}$ and $\mathrm{PN}_{10}$ mixing ratios and concentrations showed second maxima during the early night hours. $\mathrm{NO}_{x}$ and $\mathrm{CO}_{2}$ peaked soon after the stabilization of the boundary layer at 1900 , while $\mathrm{NH}_{3}, \mathrm{PM}_{10}$ and $\mathrm{PN}_{10}$ had their nocturnal maxima around 2000 . This pattern was likely caused by the less pronounced mixing within the nocturnal boundary layer during stable atmospheric conditions combined with a still high traffic density. Gong et al. (2011) also observed a similar diurnal $\mathrm{NH}_{3}$ cycle during August 2010 to September 2010 with a morning peak at 1100 , a decrease during midday and a nighttime increase. This diurnal cycle has been typical for urban ammonia concentrations in many cities (Olszyna et al., 2005; Sudheer and Rengarajan, 2015). A nighttime peak of PM was also observed in an urban, industrial area of southern Taiwan, where the nocturnal maximum even exceeded the daytime peak (Tsai et al., 2014).

Note that air temperature and $\mathrm{rH}$ apparently had no influence on the temporal dynamics of $\mathrm{NH}_{3}$ in Münster, which contradicts most previous studies (Baek et al., 2004; Behera and Sharma, 2010; Shen et al., 2011). This missing correlation between air temperature and $\mathrm{rH}$ and ammonia concentrations was observed for Münster before (Vogt et al., 2005). If vaporization of particulate $\mathrm{NH}_{4}{ }^{+}$was important, an increase of gaseous $\mathrm{NH}_{3}$ should have occurred during increasing temperature and decreasing $\mathrm{rH}$ until 1600, but that was not the case. Nevertheless, the high overall mean $\mathrm{NH}_{3}$ mixing ratio may have been influenced by the increased volatilization of ammonia due to high air temperatures during the measurement campaign (mean: $20.7^{\circ} \mathrm{C}$ ). A seasonal pattern with higher $\mathrm{NH}_{3}$ concentrations during summer was for example observed in central Taiwan (Lin et al., 2006) and mainland China (Shen et al., 2011). The mean wind speed during the nine-week campaign was relatively low $\left(1.0 \mathrm{~m} \mathrm{~s}^{-1}\right.$ ) (Fig. 1(b)), so, the transport of air out of the street canyon was not very pronounced. Therefore, emission sources were apparently more important than meteorological conditions.

The pollutant ratios during daytime and nighttime peaks can give insight into the sources of the pollutants (Table 4). If the pollutant ratios of the two daily peaks differ, it is likely that the daytime and nighttime sources are also not identical. The midday $\mathrm{NH}_{3} / \mathrm{NO}_{x}$ peak ratio was 3.2 times higher $\left(0.121 \mathrm{~g} \mathrm{~g}^{-1}\right)$ compared to the nighttime ratio $\left(0.038 \mathrm{~g} \mathrm{~g}^{-1}\right)$. Also, the $\mathrm{NH}_{3} / \mathrm{CO}_{2}$ peak ratio was 1.5 times higher during daytime. This higher daytime ratio of $\mathrm{NH}_{3} / \mathrm{NO}_{\mathrm{x}}$ and $\mathrm{NH}_{3} / \mathrm{CO}_{2}$ supports our assumption that agriculture was the main ammonia source during the day.

Thus, during stable atmospheric conditions at night, both $\mathrm{NH}_{3}$ and $\mathrm{NO}_{x}$ were emitted mainly from catalysts of both gasoline and diesel vehicles. Together with the high amount of ammonia present due to agricultural activities the excess $\mathrm{NO}_{\mathrm{x}}$ degrades the urban air quality in Münster and has potentially negative impacts on human health.

Table 4. Median peak emission ratios of the detected peak intervals of $\mathrm{NH}_{3} / \mathrm{CO}_{2}, \mathrm{NO}_{\mathrm{x}} / \mathrm{CO}_{2}$, $\mathrm{NH}_{3} / \mathrm{NO}_{x}$ for the measurement campaign during daytime and nighttime, respectively.

\begin{tabular}{lll}
\hline Emission ratio $\left[\mathrm{g} \mathrm{g}^{-1}\right]$ & Daytime & Nighttime \\
\hline $\mathrm{NH}_{3} / \mathrm{CO}_{2}$ & $1.03 \times 10^{-4}$ & $6.90 \times 10^{-5}$ \\
$\mathrm{NO}_{x} / \mathrm{CO}_{2}$ & $8.52 \times 10^{-4}$ & $1.82 \times 10^{-3}$ \\
$\mathrm{NH}_{3} / \mathrm{NO}_{x}$ & $1.21 \times 10^{-1}$ & $3.80 \times 10^{-2}$ \\
\hline
\end{tabular}




\subsection{Contribution of Ammonia to PM Formation}

Ammonia is an important gas-phase precursor for PM due to its ability to form particulate ammonium salts (Perrino et al., 2002; Kirkby et al., 2011). Given the high ammonia mixing ratio during the measurement campaign, $\mathrm{NH}_{3}$ likely contributed significantly to the formation of secondary PM in the urban air. The analysis of inorganic ions showed that the ammonium ion did indeed play an important role in the inorganic PM composition across all particle sizes with diameters from $0.05 \mu \mathrm{m}$ to $10 \mu \mathrm{m}$ (five size ranges) (Fig. 6). $\mathrm{NH}_{4}{ }^{+}$was even the major component in the accumulation mode of PM ranging from $0.14 \mu \mathrm{m}$ to $0.71 \mu \mathrm{m}$ in diameter. The reactions of gaseous $\mathrm{NH}_{3}$ with acidic gases (left-hand sides of reactions (2) and (3)) to form particulate $\mathrm{NH}_{4}{ }^{+}$ (right-hand sides of reactions (2) and (3)) played apparently an essential role for PM formation in Münster (reactions (2) and (3)).

$$
\begin{aligned}
& \mathrm{NH}_{3}+\mathrm{H}_{2} \mathrm{SO}_{4} \leftrightarrow \mathrm{NH}_{4} \mathrm{HSO}_{4} \\
& \mathrm{NH}_{3}+\mathrm{HNO}_{3} \leftrightarrow \mathrm{NH}_{4} \mathrm{NO}_{3}
\end{aligned}
$$

This finding is in good correspondence with our former result that the main sources for $\mathrm{NH}_{3}$ at the site are emissions by surrounding agricultural activities. The high amounts of ammonium in the accumulation mode of PM point to medium-range transported particles from rural areas outside the city. Ammonium was also found to be the major inorganic ion in accumulation-mode PM collected in Münster at a site upwind of the city (Vogt et al., 2005). A study in the U.S. observed a synchronous increase in ammonia and ammonium around mid-day indicating that $\mathrm{NH}_{3}$ contributes to aerosol particle mass (Gong et al., 2013). Ammonia was also identified as important for SPF in India (Behera and Sharma, 2010), Japan (Sakurai and Fujita, 2002; Aikawa et al., 2005), Korea (Phan et al., 2013), mainland China (Hu et al., 2008; Shen et al., 2011) and Taiwan (Tsai et al., 2014). The second most abundant inorganic ion components in PM were nitrate and sulfate, followed by chloride (Fig. 6). A study in Taiwan found a similar contribution of water-soluble ionic species to $\mathrm{PM}$ with $\mathrm{NH}_{4}{ }^{+}$especially dominant in the size range from $0.1 \mu \mathrm{m}$ to $1 \mu \mathrm{m}$ (78\%) (Tsai et al., 2014). Nitrate and sulfate both stem from the combustion of fossil fuels, while chloride originates from sea salt aerosol. As the temperatures during the measurement period were relatively high and domestic heating thus very low, it is likely that road traffic was a major source for particulate $\mathrm{NO}_{3}{ }^{-}$and $\mathrm{SO}_{4}{ }^{2-}$ during the day in Münster. The locally emitted exhaust compounds then react with the gaseous ammonia, which originated mostly from agricultural areas outside the city. Studies from central and southern Taiwan concluded that nitrate concentrations might be even higher during the night, when $\mathrm{NO}_{3}{ }^{-}$is thermally more stable (Lin et al., 2006; Tsai et al., 2014). Former measurements of inorganic ion concentrations in Münster (Vogt et al., 2005) support the presumption that the concentrations of secondary inorganic PM were likely higher during

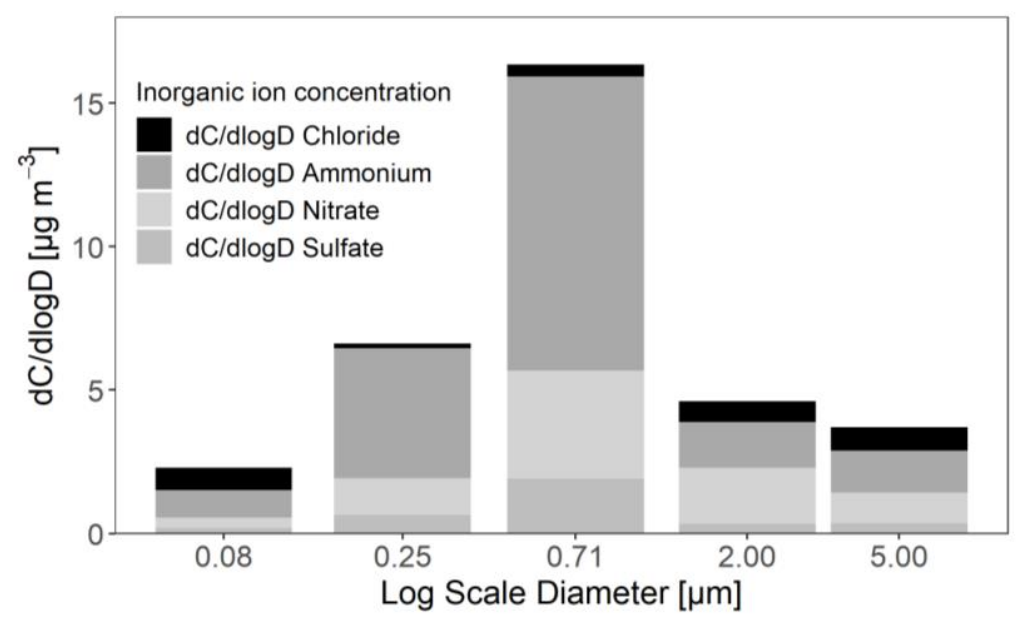

Fig. 6. Chemical composition of PM collected with the Berner Impactor. The stacked bar plots show the concentrations of the inorganic anions nitrate, sulfate and chloride and the cation ammonium. 
nighttime also in our case. Additionally, it is probable that nitrate and sulfate were transported into the city in the form of ammonium salts. This process would explain the coincidental dominance of ammonium, nitrate and sulfate in the accumulation range particle fraction (Fig. 6).

The mean molar ratio (MMR) of $\mathrm{NH}_{4}{ }^{+} / \mathrm{SO}_{4}{ }^{2-}$ gives insight on the abundance of ammonia with respect to its potential to neutralize $\mathrm{H}_{2} \mathrm{SO}_{4}$ (Behera and Sharma, 2010; Seinfeld and Pandis, 2016). Behera and Sharma (2010) found that the formation of $\left(\mathrm{NH}_{4}\right)_{2} \mathrm{SO}_{4}$ is favoured (S-conversion ratio $\left.=F_{s}: 58 \%\right)$ over the formation of $\mathrm{NH}_{4} \mathrm{NO}_{3}$ (N-conversion ratio = $\mathrm{F}_{\mathrm{n}}$ : 39\%). The PM in Münster showed a MMR of 2.7 for $\mathrm{NH}_{4}{ }^{+} / \mathrm{SO}_{4}{ }^{2-}$. Mean molar ratios $>2$ indicate that high amounts of excess ammonia are available for chemical reactions other than the formation of $\left(\mathrm{NH}_{4}\right)_{2} \mathrm{SO}_{4}$. It is therefore likely that, in addition to the formation of ammonium sulfate and ammonium bisulfate, also high amounts of $\mathrm{NH}_{4} \mathrm{NO}_{3}$ are formed in Münster. Our results are similar with those from an urban site in India (MMR of $\mathrm{NH}_{4}{ }^{+} / \mathrm{SO}_{4}{ }^{2-}=2.8$ ) (Behera and Sharma, 2010) and one in southern Taiwan (MMR of $\mathrm{NH}_{4}{ }^{+} / \mathrm{SO}_{4}{ }^{2-}=3.2$ ) (Tsai et al., 2014), which both observed ammonium-rich aerosol. To further assess the capability of ammonia to neutralize not only $\mathrm{H}_{2} \mathrm{SO}_{4}$, but also $\mathrm{HNO}_{3}$, the ammonium neutralization index J for the collected PM was calculated.

$$
J=\frac{\left[\mathrm{NH}_{4}^{+}\right]}{2 \times\left[\mathrm{SO}_{4}^{-}\right]+\left[\mathrm{NO}_{3}^{-}\right]} \times 100 \%
$$

when $\mathrm{J}<100 \%$ a $\mathrm{NH}_{4}{ }^{+}$deficit is present, while at $\mathrm{J}=100 \%$ the particles are neutral, and for $\mathrm{J}>$ $100 \%$ there is an excess of ammonium with the consequence that PM tends to be alkaline. Unfortunately, the complete charge balance could not be calculated due to missing measurements of the cations besides $\mathrm{NH}_{4}{ }^{+}\left(\mathrm{K}^{+}, \mathrm{Ca}^{2+}, \mathrm{Na}^{+}\right)$, but ammonium is assumed to be dominant at the site. The $\mathrm{J}$ index was $113 \%$ for the PM samples collected during our campaign, which is comparable to a study in India reporting a J index of $111 \%$ (Behera and Sharma, 2010). Thus, there was a distinct excess of $\mathrm{NH}_{4}{ }^{+}$present at the measurement site in the city center of Münster. As ammonia is so abundant, the reduction of $\mathrm{NH}_{3}$ emissions would have to be massive to achieve a detectable effect on air quality. Therefore, it might be more promising on the short-term to further reduce other traffic-related compounds like $\mathrm{NO}_{x}$ and $\mathrm{SO}_{2}$. If these limiting compounds are not present for the reaction with ammonia, no ammonium salts can be produced and the SPF is suppressed. Nevertheless, a long-term reduction of ammonia will be beneficial not only for urban air quality, but also to remedy other environmental issues (eutrophication of natural ecosystems, pollution of groundwater and streams).

\section{CONCLUSIONS}

Overall, the typical dynamic stop and go driving pattern at the urban site led to highly variable peak emissions of $\mathrm{NH}_{3}$ in Münster. The real-world emissions of $\mathrm{NH}_{3}$ are similar to the theoretical emissions predicted by the HBEFA, but under real-world conditions the variance across the vehicle fleet was greater. TWC systems of gasoline vehicles and SCR catalysts of diesel engines are responsible for these local emissions of $\mathrm{NH}_{3}$. All in all, road traffic was only a minor source for ammonia in Münster. The mean diurnal mixing ratios revealed that the main source of $\mathrm{NH}_{3}$ was emissions from agricultural activities. Ammonia was transported from rural areas into the city and accumulated in the residual layer above the city during the night. In the late morning hours, $\mathrm{NH}_{3}$ was mixed into the urban $\mathrm{BL}$ as soon as the dynamic atmospheric stability became unstable. Despite its origin, ammonia has important implications for the air quality in Münster. Ammonium was an important component of PM in the size fractions from $0.05 \mu \mathrm{m}$ to $10 \mu \mathrm{m}$ together with nitrate and sulfate, indicating that ammonium salts were a major component of inorganic PM at the urban site. The interplay of combustion emissions from traffic $\left(\mathrm{NO}_{x}, \mathrm{SO}_{2}\right)$ and $\mathrm{NH}_{3}$ from agriculture has important implications for particle formation and particle dynamics. To effectively enhance urban air quality, besides sulfur and nitrogen oxides, also ammonia emissions have to be reduced. This claim is not unique for Münster, but also valid for many other regions as e.g., China (Shen et al., 2011) or the U.S. (Pinder et al., 2007). Backes et al. (2016) estimated that a $50 \%$ reduction of $\mathrm{NH}_{3}$ emissions would result in a reduction of $\mathrm{PM}_{2.5}$ concentrations up to $25 \%$ in winter. In the case of Münster, the atmosphere is so rich in ammonia that it would be more 
effective to further reduce its reaction partners $\mathrm{NO}_{x}$ and $\mathrm{SO}_{2}$ in order to enhance air quality on a short-term perspective. This suggests the further promotion of SCR catalyst systems to reduce traffic-related $\mathrm{NO}_{x}$ because that reduces the formation of $\mathrm{PM}$ more than the additional emissions of $\mathrm{NH}_{3}$ associated with it will increase it. On the long-term, it is nevertheless advisable to reduce agricultural ammonia emissions. Paulot and Jacob (2014) estimated that the reduction of $\mathrm{NH}_{3}$ from livestock operations would lead to greater health benefits than the decrease of National Ambient Air Quality Standards for $\mathrm{PM}_{2.5}$ from $15 \mu \mathrm{m}^{3}$ to $12 \mu \mathrm{m}^{3}$ in the U.S. All in all, policymakers and municipalities should include emissions from agriculture into urban air pollution mitigation plans to successfully enhance air quality in cities.

The semi-empirical peak detection method successfully estimated real-world peak ratios of $\mathrm{NH}_{3} / \mathrm{CO}_{2}$. The method has some limitations due to possible time delays of the respective peaks of the different air pollutants and transport pathways of the exhaust plumes, but the large number of analysed plumes led to robust conclusions with respect to the vehicle fleet that passed the measurement site during the experimental period.

\section{ACKNOWLEDGMENTS}

We like to thank the German Research Foundation (DFG) for founding this project (Project-ID: KL 623/21-1). We are furthermore grateful to Laura Goulier and Bastian Paas, who helped with field work during the measurement campaign. We also acknowledge the cooperation with the municipalities of the city of Münster. We thank Stephen M. Griffith for language editing of the manuscript and two anonymous reviewers of an earlier version of the manuscript, who helped to improve it significantly.

\section{DISCLAIMER}

The authors have no conflict of interest concerning the scope of this study.

\section{REFERENCES}

Aikawa, M., Hiraki, T., Tamaki, M. (2005). Characteristics in concentration of chemical species in ambient air based on three-year monitoring by filter pack method. Water Air Soil Pollut. 161, 335-352. https://doi.org/10.1007/s11270-005-4774-9

Aneja, V.P., Chauhan, J.P., Walker, J.T. (2000). Characterization of atmospheric ammonia emissions from swine waste storage and treatment lagoons. J. Geophys. Res. 105, 1153511545. https://doi.org/10.1029/2000JD900066

Backes, A.M., Aulinger, A., Bieser, J., Matthias, V., Quante, M. (2016). Ammonia emissions in Europe, part II: How ammonia emission abatement strategies affect secondary aerosols. Atmos. Environ. 126, 153-161. https://doi.org/10.1016/j.atmosenv.2015.11.039

Baek, B.H., Aneja, V.P., Tong, Q. (2004). Chemical coupling between ammonia, acid gases, and fine particles. Environ. Pollut. 129, 89-98. https://doi.org/10.1016/j.envpol.2003.09.022

Baer, D., Gupta, M., Leen, J.B., Berman, E. (2012). Environmental and Atmospheric Monitoring Using Off-Axis Integrated Cavity Output Spectroscopy (OA-ICOS). American Laboratory. http://www.americanlaboratory.com/913-Technical-Articles/125787-Environmental-andAtmospheric-Monitoring-Using-Off-Axis-Integrated-Cavity-Output-Spectroscopy-OA-ICOS/ (accessed 27 November 2017).

Baptiste, A. (2017). gridExtra: Miscellaneous Functions for "Grid" Graphics. R package version 2.3. https://CRAN.R-project.org/package=gridExtra

Baptiste, A. (2019). egg: Extensions for 'ggplot2': Custom Geom, Custom Themes, Plot Alignment, Labelled Panels, Symmetric Scales, and Fixed Panel Size. R package version 0.4.5. https://CRAN.R-project.org/package=egg

Battye, W. (2003). Evaluation and improvement of ammonia emissions inventories. Atmos. Environ. 37, 3873-83. https://doi.org/10.1016/S1352-2310(03)00343-1

Behera, S.N., Sharma, M. (2010). Investigating the potential role of ammonia in ion chemistry of 
fine particulate matter formation for an urban environment. Sci. Total Environ. 408, 35693575. https://doi.org/10.1016/j.scitotenv.2010.04.017

Benson, D.R., Yu, J.H., Markovich, A., Lee, S.H. (2011). Ternary homogeneous nucleation of $\mathrm{H}_{2} \mathrm{SO}_{4}$, $\mathrm{NH}_{3}$, and $\mathrm{H}_{2} \mathrm{O}$ under conditions relevant to the lower troposphere. Atmos. Chem. Phys. 11, 4755-4766. https://doi.org/10.5194/acp-11-4755-2011

Bielaczyc, P., Szczotka, A., Swiatek, A., Woodburn, J. (2012). A Comparison of ammonia emission factors from light-duty vehicles operating on gasoline, liquefied petroleum gas (LPG) and compressed natural gas (CNG). SAE Int. J. Fuels Lubr. 5, 751-759. https://doi.org/10.4271/201201-1095

Boyce, M.P. (2012). 10 - Combustors, in: Boyce, M.P. (Ed.), Gas Turbine Engineering Handbook (Fourth Edition), Butterworth-Heinemann, Oxford, pp. 427-490. https://doi.org/10.1016/B9780-12-383842-1.00010-X

Bundesministerium für Verkehr und digitale Infrastruktur (BMVI) (2016). Berichte der Untersuchungskommission „Volkswagen“. https://www.bmvi.de/blaetterkatalog/catalogs/23 5222/pdf/save/bk_1.pdf

Carslaw, D.C., Ropkins, K. (2012). openair - An R package for air quality data analysis. Environ. Modell. Software 27-28, 52-61. https://doi.org/10.1016/j.envsoft.2011.09.008

Clarisse, L., Clerbaux, C., Dentener, F., Hurtmans, D., Coheur, P.F. (2009). Global ammonia distribution derived from infrared satellite observations. Nat. Geosci. 2, 479-483. https://doi.org/10.1038/ngeo551

Dammers, E., Vigouroux, C., Palm, M., Mahieu, E., Warneke, T., Smale, D., Langerock, B., Franco, B., Van Damme, M., Schaap, M., Notholt, J., Erisman, J.W. (2015). Retrieval of ammonia from ground-based FTIR solar spectra. Atmos. Chem. Phys. 15, 12789-12803. https://doi.org/10.51 94/acp-15-12789-2015

Dowle, M., Srinivasan, A., Gorecki, J., Chirico, M., Stetsenko, P., Short, T., Lianoglou, S., Antonyan, E., Bonsch, M., Parsonage, H., Ritchie, S., Ren, K., Tan, X., Saporta, R., Seiskari, O., Dong, X., Lang, M., Iwasaki, W., Wenchel, S., Broman, K., ... Schwen, B. (2019). data.table: Extension of "data.frame." R package version 1.12.8. https://CRAN.R-project.org/package=data.table

Eggleston, H.S. (1992). An improved U.K. ammonia emission inventory. Laxenburg, Austria: IIASA. pp. 95-107.

Emitec GmbH (2006). Perspectives on Mobile SCR Technology. With the assistance of E. Jacob.

European Environment Agency (EEA) (2007). Air pollution in Europe 1990 - 2004: EEA Report. No 2/2007. http://www.env-edu.gr/Documents/Air\%20pollution\%20in\%20Europe\%201990\%E2 $\% 80 \% 932004$.pdf

European Environment Agency (EEA) (2010). Ammonia $\left(\mathrm{NH}_{3}\right)$ emissions. https://www.eea. europa.eu/data-and-maps/indicators/eea-32-ammonia-nh3-emissions-1

Fellows, I., Stotz, J.P. (2019). OpenStreetMap: Access to Open Street Map Raster Images. R package version 0.3.4. Using the JMapViewer library by Jan Peter Stotz. https://CRAN.Rproject.org/package=OpenStreetMap

Ferm, M., Hellsten, S. (2012). Trends in atmospheric ammonia and particulate ammonium concentrations in Sweden and its causes. Atmos. Environ. 61, 30-39. https://doi.org/10.1016/ j.atmosenv.2012.07.010

Ferrara, R.M., Loubet, B., Di Tommasi, P., Bertolini, T., Magliulo, V., Cellier, P., Eugster, W., Rana, G. (2012). Eddy covariance measurement of ammonia fluxes: Comparison of high frequency correction methodologies. Agric. For. Meteorol. 158-159, 30-42. https://doi.org/10.1016/j.ag rformet.2012.02.001

Fraser, M.P., Cass, G.R. (1998). Detection of excess ammonia emissions from in-use vehicles and the implications for fine particle control. Environ. Sci. Technol. 32, 1053-1057. https://doi.org/ 10.1021/es970382h

Frieling, D. (2014). Wirkung von Stickstoff-Einträgen auf die Umwelt: Situation in NRW. Fachgespräch Stickstoffbilanzen, 2014.

Fu, M., Ge, Y., Wang, X., Tan, J., Yu, L., Liang, B. (2013). NOx emissions from Euro IV busses with SCR systems associated with urban, suburban and freeway driving patterns. Sci. Total Environ. 452-453, 222-226. https://doi.org/10.1016/j.scitotenv.2013.02.076

Gagolewski, M. (2020). R package stringi: Character string processing facilities. http://ww w.gagolewski.com/software/stringi/ 
Gong, L., Lewicki, R., Griffin, R.J., Flynn, J.H., Lefer, B.L., Tittel, F.K. (2011). Atmospheric ammonia measurements in Houston, TX using an external-cavity quantum cascade laser-based sensor. Atmos. Chem. Phys. 11, 9721-9733. https://doi.org/10.5194/acp-11-9721-2011

Gong, L., Lewicki, R., Griffin, R.J., Tittel, F.K., Lonsdale, C.R., Stevens, R.G., Pierce, J.R., Malloy, Q.G.J., Travis, S.A., Bobmanuel, L.M., Lefer, B.L., Flynn, J.H. (2013). Role of atmospheric ammonia in particulate matter formation in Houston during summertime. Atmos. Environ. 77, 893-900. https://doi.org/10.1016/j.atmosenv.2013.04.079

Gordon, G.E. (1988). Chemistry of the natural atmosphere. Peter Warneck. Academic Press, San Diego, CA, 1988. xiv, 757 pp., illus. \$85. International Geophysics Series, vol. 41. Science 242, 121-122. https://doi.org/10.1126/science.242.4875.121-a

Goulier, L., Paas, B., Ehrnsperger, L., Klemm, O. (2020). Modelling of urban air pollutant concentrations with artificial neural networks using novel input variables. Int. J. Environ. Res. Public Health 17, 2025. https://doi.org/10.3390/ijerph17062025

Hanson, D.R., Eisele, F.L., Ball, S.M., McMurry, P.M. (2002). Sizing small sulfuric acid particles with an ultrafine particle condensation nucleus counter. Aerosol Sci. Technol. 36, 554-559. https://doi.org/10.1080/02786820252883793

Hu, M., Wu, Z., Slanina, J., Lin, P., Liu, S., Zeng, L. (2008). Acidic gases, ammonia and water-soluble ions in $\mathrm{PM}_{2.5}$ at a coastal site in the Pearl River Delta, China. Atmos. Environ. 42, 6310-6320. https://doi.org/10.1016/j.atmosenv.2008.02.015

Huai, T., Durbin, T.D., Miller, J.W., Pisano, J.T., Sauer, C.G., Rhee, S.H., Norbeck, J.M. (2003). Investigation of $\mathrm{NH}_{3}$ emissions from new technology vehicles as a function of vehicle operating conditions. Environ. Sci. Technol. 37, 4841-4847. https://doi.org/10.1021/es030403+

Huai, T., Durbin, T.D., Younglove, T., Scora, G., Barth, M., Norbeck, J.M. (2005). Vehicle specific power approach to estimating on-road $\mathrm{NH}_{3}$ emissions from light-duty vehicles. Environ. Sci. Technol. 39, 9595-9600. https://doi.org/10.1021/es050120c

Kean, A.J., Littlejohn, D., Ban-Weiss, G.A., Harley, R.A., Kirchstetter, T.W., Lunden, M.M. (2009). Trends in on-road vehicle emissions of ammonia. Atmos. Environ. 43, 1565-1570. https://doi.org/10.1016/j.atmosenv.2008.09.085

Kim, Y.J., Kwon, H.J., Heo, I., Nam, I.-S., Cho, B.K., Choung, J.W., Cha, M.-S., Yeo, G.K. (2012). Mn$\mathrm{Fe} / \mathrm{ZSM} 5$ as a low-temperature SCR catalyst to remove $\mathrm{NO}_{\mathrm{x}}$ from diesel engine exhaust. Appl. Catal., B 126, 9-21. https://doi.org/10.1016/j.apcatb.2012.06.010

Kirkby, J., Curtius, J., Almeida, J., Dunne, E., Duplissy, J., Ehrhart, S., Franchin, A., Gagné, S., Ickes, L., Kürten, A., Kupc, A., Metzger, A., Riccobono, F., Rondo, L., Schobesberger, S., Tsagkogeorgas, G., Wimmer, D., Amorim, A., Bianchi, F., Breitenlechner, M., ... Kulmala, M. (2011). Role of sulphuric acid, ammonia and galactic cosmic rays in atmospheric aerosol nucleation. Nature 476, 429-433. https://doi.org/10.1038/nature10343

Lammers, Marianne, and Thorsten Becker (2014). Landwirtschaft im Münsterland: Daten - Fakten - Analysen. 2. Auflage

LI-COR Inc. (2009). LI-7500A Open Path $\mathrm{CO}_{2} / \mathrm{H}_{2} \mathrm{O}$ Analyzer Instruction Manual. Publication NO. 984-10563.

Lin, Y., Cheng, M., Ting, W., Yeh, C. (2006). Characteristics of gaseous $\mathrm{HNO}_{2}, \mathrm{HNO}_{3}, \mathrm{NH}_{3}$ and particulate ammonium nitrate in an urban city of Central Taiwan. Atmos. Environ. 40, 472533. https://doi.org/10.1016/j.atmosenv.2006.04.037

Livingston, C., Rieger, P., Winer, A. (2009). Ammonia emissions from a representative in-use fleet of light and medium-duty vehicles in the California South Coast Air Basin. Atmos. Environ. 43, 3326-3333. https://doi.org/10.1016/j.atmosenv.2009.04.009

Matzer, C., Weller, C., Dippold, M., Lipp, S., Röck, M., Rexeis, M., Hausberger, S. (2019). Update of Emission Factors for HBEFA Version 4.1: Final report. I-05/19/CM EM-I-16/26/679.

McMurry, P.H., Fink, M., Sakurai, H., Stolzenburg, M.R., Mauldin, R.L., Smith, J., Eisele, F., Moore, K., Sjostedt, S., Tanner, D., Huey, L.G., Nowak, J.B., Edgerton, E., Voisin, D. (2005). A criterion for new particle formation in the sulfur-rich Atlanta atmosphere. J. Geophys. Res. 110, D22S02. https://doi.org/10.1029/2005JD005901

Miller, D.J., Sun, K., Tao, L., Khan, M.A., Zondlo, M.A. (2014). Open-path, quantum cascade-laserbased sensor for high-resolution atmospheric ammonia measurements. Atmos. Meas. Tech. 7, 81-93. https://doi.org/10.5194/amt-7-81-2014

Moeckli, M.A., Fierz, M., Sigrist, M.W. (1996). Emission factors for ethene and ammonia from a 
tunnel study with a photoacoustic trace gas detection system. Environ. Sci. Technol. 30, 28642867. https://doi.org/10.1021/es960152n

Moravek, A., Murphy, J.G., Hrdina, A., Lin, J.C., Pennell, C., Franchin, A., Middlebrook, A.M., Fibiger, D.L., Womack, C.C., McDuffie, E.E., Martin, R., Moore, K., Baasandorj, M., Brown, S.S. (2019). Wintertime spatial distribution of ammonia and its emission sources in the Great Salt Lake region. Atmos. Chem. Phys. 19, 15691-15709. https://doi.org/10.5194/acp-19-156912019

Müller, W., Ölschlegel, H., Schäfer, A., Hakim, N., Binder, K. (2003). Selective Catalytic Reduction - Europe's NOx Reduction Technology. In SAE Technical Paper Series. SAE Technical Paper Series: SAE International400 Commonwealth Drive, Warrendale, PA, United States.

Nowak, J.B., Neuman, J.A., Kozai, K., Huey, L.G., Tanner, D.J., Holloway, J.S., Ryerson, T.B., Frost, G.J., McKeen, S.A., Fehsenfeld, F.C. (2007). A chemical ionization mass spectrometry technique for airborne measurements of ammonia: AIRBORNE CIMS NH 3 MEASUREMENTS. J. Geophys. Res. 112, D10S02. https://doi.org/10.1029/2006JD007589

Nowak, J.B., Neuman, J.A., Bahreini, R., Brock, C.A., Middlebrook, A.M., Wollny, A.G., Holloway, J.S., Peischl, J., Ryerson, T.B., Fehsenfeld, F.C. (2010). Airborne observations of ammonia and ammonium nitrate formation over Houston, Texas. J. Geophys. Res. 115, D22304. https://doi.org/10.1029/2010JD014195

Olivier, J.G.J., Bouwman, A.F., Van der Hoek, K.W., Berdowski, J.J.M. (1998). Global air emission inventories for anthropogenic sources of $\mathrm{NO}_{x}, \mathrm{NH}_{3}$ and $\mathrm{N}_{2} \mathrm{O}$ in 1990. Environ. Pollut. 102, 135148. https://doi.org/10.1016/S0269-7491(98)80026-2

Olszyna, K.J., Bairai, S.T., Tanner, R.L. (2005). Effect of ambient $\mathrm{NH}_{3}$ levels on $\mathrm{PM}_{2.5}$ composition in the Great Smoky Mountains National Park. Atmos. Environ. 39, 4593-4606. https://doi.org/ 10.1016/j.atmosenv.2005.04.011

Paulot, F., Jacob, D.J. (2014). Hidden Cost of U.S. agricultural exports: Particulate matter from ammonia emissions. Environ. Sci. Technol. 48, 903-908. https://doi.org/10.1021/es4034793

Peitzmeier, C., Loschke, C., Wiedenhaus, H., Klemm, O. (2017). Real-world vehicle emissions as measured by in situ analysis of exhaust plumes. Environ. Sci. Pollut. Res. 24, 23279-23289. https://doi.org/10.1007/s11356-017-9941-1

Perrino, C., Catrambone, M., Di Menno Di Bucchianico, A., Allegrini, I. (2002). Gaseous ammonia in the urban area of Rome, Italy and its relationship with traffic emissions. Atmos. Environ. 36, 5385-5394. https://doi.org/10.1016/S1352-2310(02)00469-7

Phan, N.T., Kim, K.H., Shon, Z.H., Jeon, E.C., Jung, K., Kim, N.J. (2013). Analysis of ammonia variation in the urban atmosphere. Atmos. Environ. 65, 177-185. https://doi.org/10.1016/j.at mosenv.2012.10.049

Pierson, W.R., Brachaczek, W.W. (1983). Emissions of ammonia and amines from vehicles on the road. Environ. Sci. Technol. 17, 757-760. https://doi.org/10.1021/es00118a013

Pinder, R.W., Adams, P.J., Pandis, S.N. (2007). Ammonia emission controls as a cost-effective strategy for reducing atmospheric particulate matter in the eastern United States. Environ. Sci. Technol. 41, 380-386. https://doi.org/10.1021/es060379a

Puchalski, M.A., Sather, M.E., Walker, J.T., Lehmann, C.M.B., Gay, D.A., Mathew, J., Robarge, W.P. (2011). Passive ammonia monitoring in the United States: Comparing three different sampling devices. J. Environ. Monit. 13, 3156. https://doi.org/10.1039/c1em10553a

R Core Team (2019). R: A language and environment for statistical computing. http://www.rproject.org/index.html

Sakurai, T., Fujita, S. (2002). Analysis of atmospheric ammonia budget for the Kanto region, Japan. Atmos. Environ. 36, 4201-4209. https://doi.org/10.1016/S1352-2310(02)00349-7

Seinfeld, J.H., Pandis, S.N. (2016). Atmospheric chemistry and physics: From air pollution to climate change. 3rd ed., Wiley.

Shen, J., Liu, X., Zhang, Y., Fangmeier, A., Goulding, K., Zhang, F. (2011). Atmospheric ammonia and particulate ammonium from agricultural sources in the North China Plain. Atmos. Environ. 45, 5033-5041. https://doi.org/10.1016/j.atmosenv.2011.02.031

Sudheer, A.K., Rengarajan, R. (2015). Time-resolved inorganic chemical composition of fine aerosol and associated precursor gases over an urban environment in western India: Gasaerosol equilibrium characteristics. Atmos. Environ. 109, 217-227. https://doi.org/10.1016/j.a tmosenv.2015.03.028 
Sun, K., Tao, L., Miller, D.J., Pan, D., Golston, L.M., Zondlo, M.A., Griffin, R.J., Wallace, H.W., Leong, Y.J., Yang, M.M., Zhang, Y., Mauzerall, D.L., Zhu, T. (2017). Vehicle emissions as an important urban ammonia source in the United States and China. Environ. Sci. Technol. 51, 2472-2481. https://doi.org/10.1021/acs.est.6b02805

Sutton, M.A, Dragosits, U., Tang, Y.S., Fowler, D. (2000). Ammonia emissions from nonagricultural sources in the UK. Atmos. Environ. 34, 855-869. https://doi.org/10.1016/S13522310(99)00362-3

Sutton, M.A., Burkhardt, J.K., Guerin, D., Fowler, D. (1995). Measurement and modelling of ammonia exchange over arable croplands, in: Heij, G.J., Erisman, J.W. (Eds.), Studies in Environmental Science, Elsevier, pp. 71-80. https://doi.org/10.1016/S0166-1116(06)80274-8

Teledyne Advanced Pollution Instrumentation (TAPI) (2012). Model M201E Ammonia Analyzer: Manual Appendum - For use with the M200E Operators Manual, P/N 04410. 05206H DCN5910.

Thoen, E. (2019). padr: Quickly Get Datetime Data Ready for Analysis. R package version 0.5.0. https://CRAN.R-project.org/package=padr

Tsai, J.H., Chang, L.P., Chiang, H.L. (2014). Airborne pollutant characteristics in an urban, industrial and agricultural complex metroplex with high emission loading and ammonia concentration. Sci. Total Environ. 494-495, 74-83. https://doi.org/10.1016/j.scitotenv.2014.0 6.120

Vogt, E., Held, A., Klemm, O. (2005). Sources and concentrations of gaseous and particulate reduced nitrogen in the city of Münster (Germany). Atmos. Environ. 39, 7393-7402. https://doi.org/10.1016/j.atmosenv.2005.09.012

Wang, C., Tan, J., Harle, G., Gong, H., Xia, W., Zheng, T., Yang, D., Ge, Y., Zhao, Y. (2019). Ammonia formation over $\mathrm{Pd} / \mathrm{Rh}$ three-way catalysts during lean-to-rich fluctuations: The Effect of the catalyst aging, exhaust temperature, lambda, and duration in rich conditions. Environ. Sci. Technol. 53, 12621-12628. https://doi.org/10.1021/acs.est.9b03893

Wang, M., Kong, W., Marten, R., He, X.-C., Chen, D., Pfeifer, J., Heitto, A., Kontkanen, J., Dada, L., Kürten, A., Yli-Juuti, T., Manninen, H.E., Amanatidis, S., Amorim, A., Baalbaki, R., Baccarini, A., Bell, D.M., Bertozzi, B., Bräkling, S., Brilke, S., ... Donahue, N.M. (2020). Rapid growth of new atmospheric particles by nitric acid and ammonia condensation. Nature 581, 184-189. https://doi.org/10.1038/s41586-020-2270-4

Wickham, H. (2009). Ggplot2: Elegant Graphics for Data Analysis. Use R. New York, SpringerVerlag New York. http://dx.doi.org/10.1007/978-0-387-98141-3

Wickham, H. (2019). stringr: Simple, Consistent Wrappers for Common String Operations. R package version 1.4.0. https://CRAN.R-project.org/package=stringr

Wickham, H., Hester, J., Chang, W. (2020). devtools: Tools to Make Developing R Packages Easier. https://CRAN.R-project.org/package=devtools

Wilke, C.O. (2019). cowplot: Streamlined Plot Theme and Plot Annotations for 'ggplot2'. R package version 1.0.0. https://CRAN.R-project.org/package=cowplot

World Health Organization (WHO) (2016). Ambient air pollution: a global assessment of exposure and burden of disease. Geneva, Switzerland.

Xu, J., Chen, Jia, Zhao, N., Wang, G., Yu, G., Li, H., Huo, J., Lin, Y., Fu, Q., Guo, H., Deng, C., Lee, S.H., Chen, Jianmin, Huang, K. (2020). Importance of gas-particle partitioning of ammonia in haze formation in the rural agricultural environment. Atmos. Chem. Phys. 20, 7259-7269. https://doi.org/10.5194/acp-20-7259-2020

Zhang, H, Wang, J. (2015). Ammonia coverage ratio and input simultaneous estimation in ground vehicle selective catalytic reduction (SCR) systems. J. Franklin Inst. 352, 708-723. https://doi.org/10.1016/j.jfranklin.2014.06.009

Zhang, L., Chen, Y., Zhao, Y., Henze, D.K., Zhu, L., Song, Y., Paulot, F., Liu, X., Pan, Y., Lin, Y., Huang, B. (2018). Agricultural ammonia emissions in China: Reconciling bottom-up and top-down estimates. Atmos. Chem. Phys. 18, 339-355. https://doi.org/10.5194/acp-18-339-2018 